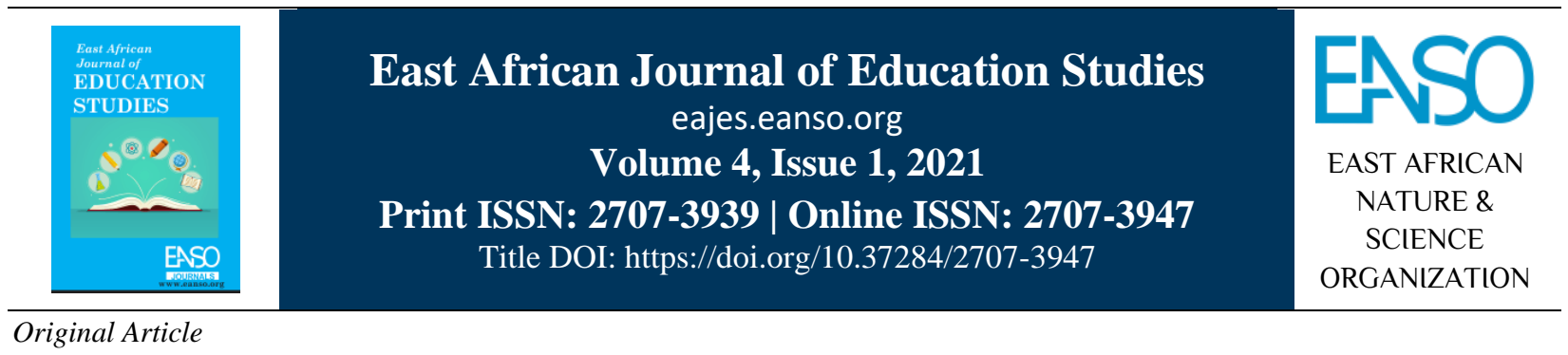

\title{
Professional Growth Opportunities and Its Influence on Job Performance of Deputy Principals of Public Secondary Schools in Lugari Sub-County, Kenya.
}

\author{
Nancy Maino, ${ }^{1 *} \&$ Dr Stephen Tomno Cheboi, $P h D^{1}$ \\ ${ }^{1}$ Mount Kenya University, P.O. Box 2591-30100, Eldoret, Kenya. \\ * Correspondence ORCID ID: https://orcid.org/0000-0002-1826-9839; Email: maino376n@ gmail.com.
}

Article DOI: https://doi.org/10.37284/eajes.4.1.515

\section{Date Published: ABSTRACT}

20 December 2021 This study sought to explore the influence of professional growth opportunities on the job performance of deputy principals of public secondary schools in

Keywords: Lugari Sub-County, Kenya. Adopting the descriptive research design, the study

Deputy Principal, utilised mixed methods approach engaging both questionnaires and interview

Professional Growth

Opportunities,

Job Performance, guide. The focus population for the study included 28 principals, 28 deputy principals and 420 teachers of public secondary schools within Lugari SubCounty. All the 28 principals and 28 deputy principals were purposively sampled for study whereas, 200 teachers were identified for study by simple

Public Secondary random sampling technique. A pilot test-retest study was conducted in three

Schools. public secondary schools from nearby Uasin Gishu County and a reliable Cronbach's Alpha coefficient of 0.79 and 0.81 was obtained for the deputy principal response questionnaire and teacher response questionnaire, respectively. Supervisors and researchers from Mount Kenya University School of education were engaged to ascertain the validity of the research instruments and necessary adjustments effected on the tools before use. The questionnaires gathered quantitative data from teachers and deputy principals whilst the interview guide assembled qualitative data from the principals. The statistical Package for Social Sciences version 23.0 was used for the analysis of quantitative data yielding frequencies, percentages, means, and standard deviation. Qualitative data were analysed thematically based on the objectives and presented along with the quantitative data. The findings established that schools in Lugari Sub County hardly support deputy principals for in-service training, the majority of deputy principals perceived unfairness in promotion procedures and that the position of deputy principal did not adequately prepare deputy principals for principal-ship. The study recommends that deputy

$119 \mid$ This work is licensed under a Creative Commons Attribution 4.0 International License. 
principals need to be supported by the school management to collaborate and improve their requisite skills to discharge their duties effectively.

\section{APA CITATION}

Maino, N., \& Cheboi, S. T. (2021). Professional Growth Opportunities and Its Influence on Job Performance of Deputy Principals of Public Secondary Schools in Lugari Sub-County, Kenya. East African Journal of Education Studies, 4(1), 119128. https://doi.org/10.37284/eajes.4.1.515.

\section{CHICAGO CITATION}

Maino, Nancy, \& Stephen Tomno Cheboi. 2021. "Professional Growth Opportunities and Its Influence on Job Performance of Deputy Principals of Public Secondary Schools in Lugari Sub-County, Kenya”. East African Journal of Education Studies 4 (1), 119-128. https://doi.org/10.37284/eajes.4.1.515.

\section{HARVARD CITATION}

Maino, N. \& Cheboi, S. T. (2021) "Professional Growth Opportunities and Its Influence on Job Performance of Deputy Principals of Public Secondary Schools in Lugari Sub-County, Kenya", East African Journal of Education Studies, 4(1), pp. 119-128. doi: 10.37284/eajes.4.1.515.

\section{IEEE CITATION}

N. Maino, \& S. T. Cheboi, "Professional Growth Opportunities and Its Influence on Job Performance of Deputy Principals of Public Secondary Schools in Lugari Sub-County, Kenya”, EAJES, vol. 4, no. 1, pp. 119-128, Dec. 2021.

\section{MLA CITATION}

Maino, Nancy, \& Stephen Tomno Cheboi. "Professional Growth Opportunities and Its Influence on Job Performance of Deputy Principals of Public Secondary Schools in Lugari Sub-County, Kenya". East African Journal of Education Studies, Vol. 4, no. 1, Dec. 2021, pp. 119-128, doi:10.37284/eajes.4.1.515.

\section{INTRODUCTION}

The educational organisation of a nation determines its growth. On this basis, education and training have been identified as the means to propel Kenya into a middle-level economy (Keiyoro, 2012). Notably, excellent instruction is a result of quality educators coupled with the appropriate running of learning institutions (Selamat, Samsu and Kamalu, 2013). However, accelerated global transformations, technological and demographical changes, increased sense of responsibility as well as weakened support systems have created additional multifaceted and complicated tasks for institutional managers (Armstrong, 2014). Demet and Erkut (2018) noted that setting the pace, aspirations, efficiency and safety at schools is a duty bestowed on the instructors and administrators. Apparently, to manage schools properly, principals need the support of all stakeholders. One such important stakeholder is the deputy principal. Barnett, Shoho and Oleszewski (2012) posit that if deputy principals assume their duties wholesomely, they stand a central position in responding to modern age school transformation realities. Hulya (2019) adds that school administrators greatly influence the climate and social practices at school, as well as learners' achievement; hence, they need proper professional development for the realisation of school goals.

The position of deputy principals is imperative to institutions owing to its historical reality worldwide. They are believed to embrace fundamental roles in schools including; the traditional function of deputising the principal, the prospective role as a preparatory stage to principal-ship and thirdly, the emergent role as an administrator (Barnett et al., 2012; Armstrong, 2009; Mortimore, Sammons, Stoll, Lewis \& Ecob, 2008). Unfortunately, many assistant principals feel unprepared for their current role (Busch, Macneil \& Baraniuk, 2012). World over, studies have indicated a number of challenges concerning deputy principals. In Florida, superintendent and district human resource executives testified to heightened difficulty in satisfying available positions for deputy principals (Maddern, 2009). In the US, Capelluti and Nye 
(2005) envisaged a countrywide scarcity of principals normally selected amid potential deputy principals. In Turkey, deputy principal's stand-in in the absence of main administrators and are in charge of routine activities, supervision of teachers and learners as well as convey challenges to the boss (Goksoy, 2016). In India, deputy principals called for additional coaching pertaining to technology and special education (Abebe et al., 2010).

Nigeria deputy principals decry unclear guidelines regarding their job description which has heightened the complexity and stress levels for holders of the position. This has made female educators hesitant to assume the position apprehensive of frequent disagreements linked to the position (Edo \& Nwosu, 2018). In Kenya, studies have eminent reports of deputy principals exiting the service, declining appointments and resigning from the position (Ndichu \& Silsil, 2007; Barasa et al., 2014; Ombuya, 2015; World Bank, 2014). Also, worth noting is the increased desire of teachers to migrate to specific schools. The transit behaviour may be informed by the work conditions and inadequacy of the deputy principals to handle increased tasks. Edo and Nwosu (2018) affirm that school managements face the novel challenge of creating a surrounding that draws, holds and inspires teachers to pride working to their full potential. One such challenge is updating teachers' proficiency through well designed professional development plans. In summary, these studies appreciate the gradual evolution of the duties of the deputy principal cognizant of learner supervision and instructional guidance as key duties for this group of school administrators.

Regrettably, scores of deputy principals expressed unpreparedness in their current assignment (Busch, Macneil \& Baranuik, 2012), positively indicating a need for meaningful and relevant professional development. While Barnett et al. (2012) highlighted that new and veteran assistant principals alike felt unprepared working with the school community, lacked understanding of some job- related expectations and were deficient in requisite organisational and managerial skills to carry out their duties. One way to overcome such challenges is through capacity building. Literature indicates a universal consent on the necessity of continuous expertise advancement in enhancing educators' professional capability with the eventual aim of improving learners' outcomes (Busch, Macneil \& Baranuik 2012; Barnett et al. 2012; Abebe, Linsey, Bonner and Heck, 2010; Komba and Nkumbi (2008); World Bank 2014). In the same vein, numerous reasons necessitate the need for enhanced professional development for deputy principals. Deputy Principals' handle a myriad of responsibilities with unclear job descriptions, coupled with the fact that they will assume office upon exit of principals with diminutive support. Deputy Principals also require support and training to handle new and emergent tasks, especially learner discipline, curriculum schedule, co-curriculum activities and fundamentals in administration. For deputy principals, professional growth is paramount as a preparation factor to principal-ship serving as an effective training base for the assumption of principal duties (Agba, Ogaboh \& Ushie, 2010) when opportunities arise.

Professional development entails shared learning opportunities and experiences in a formal or informal perspective amid associates in occupational teams or peers (Hulya, 2019). Diverse connotations have been assigned including staff development, in-service training, professional learning or continuing education. Deputy principals are earmarked for professional development since their novel tasks call for skills to interpret emerging guidelines and plans of action as well as gain support in discharging duties (World Bank, 2014). Worth noting is that mentorship plans are progressively vanishing away and the new responsibility may be an uphill task to handle for the new administrators. Kennedy (2016) posits vital competencies in a job is a long-term process, and without professional development, job performance 
may be greatly compromised. In addition, the everchanging technological world, techniques for instruction and methods, policies, and students learning needs automatically trigger the need for professional competencies among teachers in order to cope (Hilton, Hilton \& Goos, 2015). These enormous tasks tied with the evolving work environment necessitates that deputy principals regularly renew their leadership and managerial competencies.

The importance of professional development can never be overemphasised; it grants educators an occasion to shuffle their habitual practice of teaching to becoming learners, providing an opportunity to receive rather than give knowledge. Through such training, the trainees acquire fresh facts and competencies that would enhance their task delivery (Hilton, Hilton \& Goos, 2015). It enables educators to frequently adapt their knowledge and practice to the changing teaching needs (Kuncoro \& Darvidi, 2017). However, deputy principals have reduced openings for professional development (World Bank 2014), triggered by general school factors that can impact teachers learning and practices. Hilton, Hilton \& Goos (2015) argue that school managerial incapacities and contradictory school ethics and practices can hinder teachers' professional erudition. Therefore, there is a need to tailor professional support and training to teachers needs and improve its usefulness as well as ensure adequate resources are availed for teachers to access the training. Of importance is the influence on educators to develop a culture of learning through a well-defined support system and incentives of self-growth.

Although Professional enlargement is identified as a means of steering enhanced job outcomes, studies have indicated that the highly valued and effective professional development courses are not accessible to many educators. A report by World Bank (2014) indicates that openings for teachers' professional growth are scarce, unreachable and disproportionately disseminated, notwithstanding the soaring desire from teachers. Similarly, only a small proportion of teachers and deputy principals have masters' degrees (Githinji, 2014; Barasa et al., 2014). Time and financial constraints have also been identified as hindrances to educators' desire to study, reflect and incorporate learnt skills into their practice.

Fredrick Hertzberg identified promotion/ growth and development as one of the satisfier factors which improves motivation at work (Vijaya \& Saxena, 2015). There is a need for schools to create and enhance the accessibility of in-service training for their employees. A work environment that supports the professional growth and development of its staff presents an opportunity for diligent job performance and personal growth. Bucheli et al. (2010) noted that previously an employee's profession was a concern of the organisation, but currently, it is an employee's own vocation and would join or leave an organisation subject to opportunities for professional development. If an organisation expresses interest in its employee's professional growth, the employees would positively identify with the organisation (Wang et al., 2014), hence strengthening employee organisation bonds. This way, employees job performance would be enhanced and organisational goals may be easily achieved. Worker's performance is determined by ability, motivation and environment (Denmar \& Maroah, 2017; Wang et al., 2014). How well schools in the Lugari subcounty have provided support for the deputy principals is yet to be exploited.

\section{Statement of the Research Problem}

Deputy Principals represent a unique cluster of teachers owing to their unique role of administrative leadership in addition to teaching. Teachers' Service Commission recognises the deputy principals' as second to principals. The position is promotional and competitive based on the career progression scale (TSC, 2019). The position also comes with special salary scales that cater for added 
responsibility based on type and population in schools. The salary scales also seek to harmonise teachers' salaries with that of other public servants. In addition to their curriculum instructions duties, the deputy principals have numerous roles and responsibilities most of which are a function of the delegators' authority of the principal. This scenario subject deputies to little decision-making autonomy posing difficulty in defining their exact roles which predisposes them to confusion and conflict hindering their effective discharge of duties. Furthermore, the government has rolled out a number of policies among them being abolition of corporal punishment, $100 \%$ transition, readmission of teenage mothers among others, that pose a challenge to the office of the deputy principals directly as discipline managers in schools. These education reforms coupled with the evolving technological advancements have disrupted the school ecosystem; as school populations increase, learner challenges increase too, handling teenage mothers and overstretched school facilities not forgetting the increasing number of teachers and support staff. The deputy principals as administrators are required to interpret the policies to stakeholders, uphold discipline at school as well as supervise curriculum implementation. These changes and reforms demand that deputy principals are well equipped and regularly renew requisite skills such as leadership, discipline management,

ICT, guiding and counselling, among others, to perform their duties diligently.

Against this backdrop, a good number of teachers including deputy principals are reported to exit teaching as a career for non-teaching related jobs in both private and public sectors. According to the Lugari Sub-County education report, 2017, four deputies exited the service, two wrote to the commission declining the offer, while a good number submitted their transfer requests to be moved to other schools. This turnover and migration upset the compositional arrangement in teacher quality, changes learner culture and inspiration and erodes staff collegiality, confidence and propagates loss of institutional knowledge which is detrimental to the school's performance in the long run. This situation raises concerns on the professional preparedness of deputy principals as the underlying reason behind the unprecedented behaviour of these vital educators. Therefore, the study aimed at probing how professional growth opportunities influenced the job performance of deputy principals of public secondary schools in Lugari Sub-County, Kenya.

\section{MATERIALS AND METHODS}

The study adopted a descriptive survey research design and employed a mixed-methods approach that collected both qualitative and quantitative data. The target population was 476 , comprising of 28 principals, 28 deputy principals and 420 teachers in 28 public secondary schools of Lugari Sub County. 200 teachers were selected by simple random sampling technique, while 28 deputy principals and 28 principals were purposively selected. The teachers sample size was established using the Taro and Yamane formula (Mugenda \& Mugenda, 2003). All 28 principals and 28 deputy principals were incorporated in the study, considering that 28 was the severe lower boundary of sample limits according to the central limit theorem (Singleton \& Royce, 1975). Three public secondary schools from the neighbouring Uasin gishu County were used for piloting the research instruments. Research instruments were adequately validated. The testretest technique was used to establish the reliability of the tools; after the computation of scores in the first and second trials, a Cronbach's Alpha coefficient of 0.8 was obtained for the deputy principal response questionnaire and 0.79 for the teacher response questionnaire. The questionnaires were used to collect quantitative data from deputy principals and teachers, while the interview guide was used to collect qualitative data from the principals. To analyse quantitative data from questionnaires, the Statistical Package for Social Sciences (SPSS) version 23.0 software was used to 
derive means, percentages, and standard deviation. On the other hand, qualitative data were analysed based on the objectives and presented thematically along with quantitative data.

\section{FINDINGS AND DISCUSSION}

The study sought to establish how professional growth opportunities influence the job performance of deputy principals in Lugari Sub County.

Table 1: Deputy Principal Responses on Effects of Professional Growth Opportunities on Job Performance

\begin{tabular}{|c|c|c|c|c|c|c|c|c|}
\hline \multirow[t]{2}{*}{ Statement } & \multicolumn{2}{|c|}{ SD/D } & \multicolumn{2}{|l|}{$\mathbf{N}$} & \multicolumn{2}{|c|}{ SA/A } & \multirow[t]{2}{*}{ Mean } & \multirow[t]{2}{*}{ SD } \\
\hline & $\mathbf{F}$ & $\%$ & $\mathbf{f}$ & $\%$ & f & $\%$ & & \\
\hline $\begin{array}{l}\text { The school supports me for in-service } \\
\text { training. }\end{array}$ & 17 & $(60.7)$ & 1 & $(3.6)$ & 10 & $(35.7)$ & 2.5357 & .51705 \\
\hline $\begin{array}{l}\text { I have been trained in discipline } \\
\text { management by the school. }\end{array}$ & 25 & $(89.3)$ & & - & 3 & $(10.7)$ & 1.9643 & .57194 \\
\hline I have been trained in ICT by the school. & 18 & $(64.3)$ & & - & 10 & $(37.5)$ & 2.4643 & .82490 \\
\hline $\begin{array}{l}\text { I have been trained in leadership by the } \\
\text { school. }\end{array}$ & 23 & $(82.1)$ & & - & 5 & $(17.9)$ & 1.7857 & .61704 \\
\hline I perceive fairness in promotion procedures. & 26 & $(92.9)$ & & - & 2 & $(7.1)$ & 1.75 & .46453 \\
\hline $\begin{array}{l}\text { The position of deputy principal adequately } \\
\text { prepares me for principal-ship. }\end{array}$ & 17 & $(60.7)$ & 5 & $(17.9)$ & 6 & $(21.4)$ & 2.3923 & .61774 \\
\hline $\begin{array}{l}\text { I am contended with the current trends of } \\
\text { promotion. }\end{array}$ & 21 & $(75.0)$ & 3 & $(10.7)$ & 4 & $(14.3)$ & 2.1071 & .57433 \\
\hline $\begin{array}{l}\text { Promotion provides me opportunities for } \\
\text { personal growth. }\end{array}$ & 12 & $(42.9)$ & 3 & (10.7) & 13 & $(46.4)$ & 3.25 & .74156 \\
\hline $\begin{array}{l}\text { Professional development is paramount to } \\
\text { my job performance at school. }\end{array}$ & 6 & $(21.4)$ & 6 & $(21.4)$ & 16 & $(57.1)$ & 3.3928 & .25816 \\
\hline $\begin{array}{l}\text { Professional skills development increases } \\
\text { my motivation to work. }\end{array}$ & 8 & $(28.6)$ & 3 & $(10.7)$ & 17 & $(60.7)$ & 3.6786 & .86187 \\
\hline
\end{tabular}

Table 2: Teachers' Responses on Effects of Professional Growth Opportunities on Job Performance of Deputy Principals

\begin{tabular}{llllllllll}
\hline Statement & \multicolumn{1}{l}{ SD/D } & N & \multicolumn{4}{c}{ SA/A } & Mean & SD \\
\cline { 2 - 7 } & $\mathbf{F}$ & $\mathbf{\%}$ & $\mathbf{f}$ & $\mathbf{\%}$ & $\mathbf{f}$ & $\mathbf{\%}$ & & \\
\hline $\begin{array}{l}\text { The school supports deputy principal for in } \\
\text { service training. }\end{array}$ & 109 & $(54.5)$ & 17 & $(8.5)$ & 74 & $(37.0)$ & 2.63 & .55577 \\
\hline $\begin{array}{l}\text { The school has trained the deputy principal } \\
\text { in discipline management. }\end{array}$ & 156 & $(78.0)$ & 12 & $(6.0)$ & 32 & $(16.0)$ & 2.235 & .88526 \\
$\begin{array}{l}\text { The school has trained the deputy principal } \\
\text { in ICT. }\end{array}$ & 113 & $(56.5)$ & 18 & $(9.0)$ & 69 & $(34.5)$ & 2.59 & .61855 \\
$\begin{array}{l}\text { The school has trained the deputy principal } \\
\text { in leadership. }\end{array}$ & 146 & $(73.0)$ & 16 & $(8.0)$ & 38 & $(19.0)$ & 1.98 & .79871 \\
\hline $\begin{array}{l}\text { The deputy principal in my school } \\
\text { perceives fairness in promotion procedures. }\end{array}$ & 112 & $(56.0)$ & 80 & $(40.0)$ & 8 & $(4.0)$ & 2.00 & .28755 \\
\hline
\end{tabular}

124| This work is licensed under a Creative Commons Attribution 4.0 International License. 
East African Journal of Education Studies, Volume 4, Issue 1, 2021

Article DOI: https://doi.org/10.37284/eajes.4.1.515

\begin{tabular}{|c|c|c|c|c|c|c|c|c|}
\hline \multirow[t]{2}{*}{ Statement } & \multicolumn{2}{|c|}{ SD/D } & \multicolumn{2}{|l|}{$\mathbf{N}$} & \multicolumn{2}{|c|}{ SA/A } & \multirow[t]{2}{*}{ Mean } & \multirow[t]{2}{*}{ SD } \\
\hline & $\mathbf{F}$ & $\%$ & $\mathbf{f}$ & $\%$ & $\mathbf{f}$ & $\%$ & & \\
\hline $\begin{array}{l}\text { The position of deputy principal adequately } \\
\text { prepares him/her for principal-ship }\end{array}$ & 116 & $(58.0)$ & 38 & (19.0) & 46 & $(23.0)$ & 2.355 & .74424 \\
\hline $\begin{array}{l}\text { The deputy principal in my school is } \\
\text { contended with the current trends in } \\
\text { promotion. }\end{array}$ & 134 & $(67.0)$ & 37 & $(18.5)$ & 29 & $(14.5)$ & 2.055 & .88526 \\
\hline $\begin{array}{l}\text { Promotions provide the deputy principal } \\
\text { opportunities for personal growth. }\end{array}$ & 86 & $(43.0)$ & 22 & $(11.0)$ & 92 & $(46.0)$ & 3.01 & .79129 \\
\hline $\begin{array}{l}\text { Professional development is paramount to } \\
\text { the deputy principals' job performance. }\end{array}$ & 57 & $(28.5)$ & 39 & $(19.5)$ & 104 & $(52.0)$ & 3.215 & .62207 \\
\hline $\begin{array}{l}\text { Professional skill development increases } \\
\text { the deputy principals' motivation to work at } \\
\text { school. }\end{array}$ & 54 & $(27.0)$ & 32 & $(16.0)$ & 114 & $(57.0)$ & 3.57 & .55680 \\
\hline
\end{tabular}

As indicated in Tables 1 and 2, at mean 2.5357 and SD .51705 and teachers at mean 2.235 and SD .55577. Respondents generally disagreed that deputy principals receive in-service training at school. The principals indicated a lack of funds in schools to support in-servicing training deputies. These findings agree with Bucheli et al. (2010), who reported that nowadays, professional growth is the discretion of employees and not the organisation. This presents a weak employee institution bond that can propel deputy principals desire to exit the profession.

Deputy Principals at the mean of 1.9643 and SD .57194 and teachers at the mean of 2.235 and SD .88526 disagreed that deputy principals are trained on discipline management by the school. Similar trends were realised in Kwazulu Natal where the majority (49\%) of teachers indicated that they were ill-prepared to deal with drug and substance abuse at school (Dehaloo, 2011). The deputy principals at the mean of 2.4643 and SD .8249 and teachers at the mean of 2.59 and SD .61855 disagreed that their deputy principal was trained in ICT by the school. Both deputy principals at mean 1.5357 and SD .78004 and teachers at the mean of 1.98 and SD .79871 generally disagreed that the deputy principals were trained in leadership by the school. Interviews with the principals revealed that discipline management, ICT, and leadership skills are important for deputy principals to effectively discharge their duties. However, they were noncommittal to facilitating the same decrying lack of funds for training. Interestingly, the principals indicated that all teachers including their deputies had been trained on Teacher Performance and Appraisal Development (TPAD), an online platform for monitoring teacher performance by the employer. This is a pointer to the prioritised areas for professional development.

Both deputy principals at mean 1.75 and SD .46453 and teachers at mean 1.75 and SD .46453 disagreed that the promotion procedure for deputy principals was fair. The interviewed principals indicated that promotions are pegged on job groups but decried delays and stagnation which discourage deputies in their job performance. In the Lumuru district, majority $47.6 \%$ of deputies were not satisfied with fairness in promotion (Githinji, 2014). In the Hamisi district, $57.57 \%$ disagreed with fairness in promotion procedures (Barasa et al., 2014). The position of deputy principal does not adequately prepare them for principal-ship. On this, deputies disagreed at the mean of 2.3923 and SD .61774 and teachers disagreed at mean 2.355 and SD .74424 The principals indicated that the position of deputy principal gives a basis to principal-ship though the 
challenges in principle-ship are unique in each school. Deputy Principals are not contented with current promotion trends disagreed at the mean of 2.1071 and SD .5743 and teachers disagreed at mean 2.355 and SD .74424. The interviewed principals hinted at delays and stagnation hampering upward mobility in ranks, lowering contentment of deputies. These results agree with Githinji (2014), who observed that deputy principals in Limuru district indicated dissatisfaction with promotion chances. The deputy principals agreed at the mean of 3.25 and SD .74156 and teachers agreed at the mean of 3.215 and SD .79129 that promotions provide deputy principals opportunities for personal growth. One principal indicated that the position of deputy principal accords them a chance for networking and exposure. Another principal said, "For teachers to climb the administrative ladder, the position of deputy principal is inevitable".

Deputy Principals agreed at the mean of 3.3928 and SD .25816 and teachers agreed at the mean of 3.215 and SD .62207 that professional development is vital in deputy principals' job performance. The principals emphasised that professional development sharpens job performance hence a vital element in any career. Similar results were posted by Komba and Kumbi (2008), where the majority $61.2 \%$ of respondents, agreed that skill progression is vital for teachers. Similarly, $42.5 \%$ of deputies in Rachuonyo Sub County indicated that professional development is important for teachers (Ombuya, 2015). Professional skill development increases deputy principals' motivation to work. Deputy Principals agreed at the mean of 3.6786 and SD .86187 and teachers agreed at the mean of 3.57 and SD .55680. The principals hinted any form of professional development propels deputies to work better. Similarly, $71.5 \%$ of deputies in Rachuonyo Sub County agreed that professional skill development motivates teachers intrinsically (Ombuya, 2015). This implies that deputy principals would have their job performance improve if they were accorded more professional growth opportunities.

\section{CONCLUSIONS}

The aim of this study was to explore how professional growth opportunities influence the job performance of deputy principals in Lugari SubCounty, Kenya. The study findings revealed that: professional development opportunities increase the deputy principal's motivation to work, accords them opportunities for personal growth hence vital for their job performance. However, a weak deputy principal school bond is exhibited due to a lack of professional support and training in ICT, leadership and discipline management. These coupled with inadequate preparation for principal-ship, stagnation and unfair promotion procedure may trigger exits or transfers of deputy principals to schools that are better placed to enhance their professional growth.

\section{Recommendation for Practice}

The findings can be used to guide education stakeholders in policy-making including creating time for school administrators to attend in-service training. The findings recommend that schools and TSC should adopt a needs-based approach to design and tailor in-service training for deputy principals. Funding for in-service training should be prioritised in school budgets. The schools' Board of Management to write policies that describe the boards' philosophy about professional development, its purpose and guidelines for its operation.

\section{Suggestion for Further Research}

This research recommends that:

- A comparable study considering deputy principals in private secondary schools whose conditions are different be carried out. 
- Similar studies are to be carried out in other subcounties and counties for corroboration now that

\section{REFERENCES}

Abebe, S., Lindsey, L., Bonner, M., \& Heck, S. (2010). Assistant principals in Indiana as Change Leaders: The need for professional development. Journal for the Liberal Arts and Sciences, 14(2), 67-73.

Agba, A. M. O., Nkpoyen, F., \& Ushie, E. M. (2010). Career development and employee commitment in industrial organisations in Calabar, Nigeria. American journal of scientific and industrial research, 1(2), 105-114.

Armstrong, D. (2014). Transition to the role of principal and vice-principal study. The Institute for Educational Leadership. Retrieved from https://education- leadershipontario. ca/medial resource/Role_of_Principal_FINAL.pdf.

Aujata, B. C., Simatwa, E. M. W., \& Yalo, A. J. (2014). Influence of Conditions of Service and Principals' Leadership on Job Satisfaction of Secondary School Deputy Principals in Kenya: A Case Study of Hamisi SubCounty. Educational Research, 5(7), 207-224.

Bucheli, M., Melgar, N., Rossi, M., \& Smith, T. W. (2010). Job satisfaction and the individual educational level, re-assessing their relationship. Documento de Trabajo/FCS-DE; $11 / 10$

Busch, S. D., MacNeil, A. J., \& Baraniuk, M. S. (2012). Critical advice from practicing assistant principals for assistant principal preparation programs. Examining the assistant principalship: New puzzles and perennial challenges for the, 21, 35-57.

Capelluti, J., \& Nye, K. (2005). The principal as salesperson. Principal Leadership (High School Ed.), 5(8), 8. education and teachers' employment is a national function.

Denmar, D., \& Marmoah, S. (2017). The Relationship Between Job Environment, Job Motivation, And Teachers Performance. IOSR Journal of Humanities and Social Science (IOSR-JHSS), 22(6), 52-60.

Dehaloo, G. (2011). The motivation and job satisfaction of secondary school teachers in KwaZulu-Natal: An education management perspective (Doctoral dissertation, University of South Africa).

Hasbay, D., \& Altındag, E. (2018). Factors that affect the performance of teachers working in secondary- level education. Academy of Educati onal Leadership Journal, 22(1), 1-19.

Edo, B. L., \& Nwosu, I. C. (2018). Working environment and teachers' productivity in secondary schools in Port-Harcourt Metropolis. International Journal of Innovative Psychology and Social Development, 6(4), 3949.

Githinji, E. W. (2014). Determinants of deputy principals' job satisfaction in public secondary schools in Limuru District, Kenya.

Göksoy, S. (2016). Leadership perceptions and competencies of deputy principals. Problems of Education in the 21st Century, 71(1), 16-30.

Hilton, A., Hilton, G., Dole, S., \& Goos, M. (2015). School leaders as participants in teachers' professional development: The impact on teachers' and school leaders' professional growth. Australian Journal of Teacher Education, 40(12), 8.

Şenol, H. (2019). Professional Development of Educational Leaders. In Educational Leadershi p. IntechOpen. 
Keiyoro, P. (2012). Task Force on the Re-Alignment of the Education Sector to the Constitution of Kenya 2010: Towards a Globally Competitive Quality Education for Sustainable Development. Ministry of Education, Nairobi, Kenya.

Kennedy, M. M. (2016). How does professional development improve teaching? Review of educational research, 86(4), 945-980.

Komba, W. L., \& Nkumbi, E. (2008). Teacher professional development in Tanzania: Perceptions and practices. Journal of international cooperation in education, 11(3), 67-83.

Kuncoro, T., \& Dardiri, A. (2017, September). Teacher performance and work environment in the instructional process in vocational school. In AIP Conference Proceedings (Vol. 1887, No. 1, p. 020043). AIP Publishing LLC.

Lugari Sub County Quality and Standards Assurance Inspection Report (2017). Assessing Factors Influencing Academic Performance in Public Secondary Schools in Lugari Sub County.

Maddern, K. (2009). Head teacher retirement time bomb delayed by recession woes. The Times Educational Supplement, 4842(11).

Mortimore, P., Sammons, P., Stoll, L., \& Ecob, R. (1988). School matters. Univ of California Press.

Mugenda, O. M., \& Mugenda, A. G. (2003). Research Methods, Quantitative and Qualitative Analysis-African Center for Technology Studies. Nairobi: Applied Research and Training Services (ACTS).

Ndichu D, Silsil, P. (2007). The Kenya handbook of teachers. Nairobi: Shrend Publishers.

Oleszewski, A., Shoho, A., \& Barnett, B. (2012). The development of assistant principals: A literature review. Journal of educational administration.
Nyakongo, O. H. (2015). Influence of motivation on teachersâ $€^{\mathrm{TM}}$ job performance in public secondary schools in Rachuonyio South SubCounty, Homa- Bay County: Kenya. Unpublish ed Master Degree Project, Kenyatta University, Kenya.

Selamat, N., Samsu, N. Z., \& Kamalu, N. S. M. (2013). The impact of organisational climate on teachers' job performance.

Singleton, L. J., \& Singleton, R. (1988). Instructor's Manual to Accompany Approaches to Social Research. Oxford University Press, USA.

Teachers Service Commission (2019, Jan-April) Teachers Image vol.22, pg 6

Vijaya, K. U. S. \& Saxena, U. (2015). Hertzberg Revisited: Dimensionality and Structural Invariance of Hertzberg's Two Factor Model. Journal of the Indian Academy of Applied Psychology 41, (2), 291

Wang, Q., Weng, Q., McElroy, J. C., Ashkanasy, N. M., \& Lievens, F. (2014). Organisational career growth and subsequent voice behavior: The role of affective commitment and gender. Journal of vocational behavior, 84(3), 431-441.

World Bank (2014). Lesotho - Public Expenditure Review PER, Washington DC; World Bank Group.

128 This work is licensed under a Creative Commons Attribution 4.0 International License. 